\title{
PHYTOREMEDIATION POTENTIAL OF Eleusine indica (L.) Gaertn, Panicum maximum Jacquin AND Lablab purpureus L. IN A CRUDE OIL POLLUTED SOIL
}

\author{
OCHEKWU, E. B ${ }^{1}$, AKPHEOKHAI, L.I ${ }^{2}$ AND ABIYA, S. E \\ ${ }^{2}$ Department of Crop Science, University of Uyo, Uyo, Akwa Ibom State, Nigeria \\ DOI: $10.31364 / S C I R J / v 8 . i 4.2020 . P 0420764$ \\ http://dx.doi.org/10.31364/SCIRJ/v8.i4.2020.P0420764
}

${ }^{1}$ Department of Plant Science and Biotechnology, University of Port Harcourt, Rivers State, Nigeria

\begin{abstract}
Eleusine indica, Panicum maximum and Lablab purpureus were screened for their potential in remediating crude oil polluted soil in microplots. Five litres plastic pots were filled with $2 \mathrm{~kg}$ soil and treated with distilled water (which served as the control - $0 \mathrm{ml}$ ) $40 \mathrm{ml}, 80 \mathrm{ml}$ and $120 \mathrm{ml}$ representing $0 \%$, $2 \%, 4 \%$ and $6 \%(\mathrm{v} / \mathrm{w})$ of crude oil, respectively. The test plants were randomly planted in the treated soil; the experiment was a $3 \times 4$ factorial in a randomized complete design with four replicates. Soil samples were collected for physicochemical parameters at the beginning and at the end of the study. Results indicated that total hydrogen hydrocarbon $(\mathrm{TPH})$ reduced significantly $(\mathrm{p} \leq 0.05)$ in the crude oil polluted soil. The TPH of $94.1 \%$ obtained was from $P$. maximum treated with $4 \% \mathrm{v} / \mathrm{w}$ crude oil, followed by $P$. maximum (94\%) treated with $6 \% \mathrm{v} / \mathrm{w}$ of crude oil. P. maximum treated with $2 \% \mathrm{v} / \mathrm{w}$ of crude oil had TPH of $82.5 \%$. L. purpureus treated with $6^{\wedge} \% \mathrm{v} / \mathrm{w}$ of crude oil reduced pollutant significantly with a TPH of $93.7 \%$ $(6 \% \mathrm{v} / \mathrm{w}), 92.7 \%(4 \% \mathrm{v} / \mathrm{w}))$ and $88.4 \%(2 \% \mathrm{v} / \mathrm{w})$. In treated $E$. indica $\mathrm{TPH}$ was $87.7 \%(2 \% \mathrm{v} / \mathrm{w}), 91.4 \%$ $(4 \% \mathrm{v} / \mathrm{w})$, and $(89.3 \%(6 \% \mathrm{v} / \mathrm{w})$ in that order. The concentration of crude oil before and after remediation ranged from $456.10-1712.20 \mathrm{mg} / \mathrm{kg}$ and $51.21-183.62 \mathrm{mg} / \mathrm{kg}$, respectively. Furthermore, there was increase in the $\mathrm{pH}$ of $P$. maximum by $35.8 \%$ at the contamination level of $6 \% \mathrm{v} / \mathrm{w}$ from $3.50-5.45 \mathrm{pH}$ pre and post remediation respectively when compared with the control. Soil cation exchange capacity reduced significantly in all tested plants with P. maximum being the least affected at all levels of crude oil pollution. There was no remediation of nitrates and phosphates by all test plants. However, phosphate in Eleusine indica treated with $6 / \% \mathrm{v} / \mathrm{w}$ of crude oil increased by $48 \%$ with the concentration of $6.50 \mathrm{mg} / \mathrm{kg}$ (pre remediation) to $12.50 \mathrm{mg} / \mathrm{kg}$ (post remediation), followed by Lablab purpureus $40.9 \%$ with concentration of $6.50-9.60 \mathrm{mg} / \mathrm{kg}$ (pre remediation) to $9.60 \mathrm{mg} / \mathrm{kg}$ (post remediation) Evidently, the tested plants have remediation potentials of crude oil polluted soil.
\end{abstract}

Keywords: Pollution, Eleusine indica, Panicum maximum, Lablab purpureus, phytoremediation, environmental degradation.

\section{INTRODUCTION}

Since oil was discovered in the Niger Delta region of Nigeria, there has been a lot of incidence of environmental degradation arising from the exploration and exploitation of this resource. This degradation arises where activities of 
oil companies and oil bunkers have compounded the environmental challenges of people of the Niger Delta region of Nigeria (Ochekwu and Madagwa, 2013). The major cause of crude oil pollution is pipeline vandalization by saboteurs seeking government attention to correct economic marginalization and ecological disaster occasioned by many years of unregulated crude oil exploration and exploitation by foreign oil companies. For this reason, research is geared towards evolving an eco-friendlier method of remediating polluted ecosystem. Phytoremediation involves the mitigation of pollutant concentrations in soils, water or air medium using plants that are able to contain, degrade or eliminate metals, pesticides, solvents, explosives, crude oil and its derivatives (Raskin, 1996). Various plants have been identified for their potential to facilitate the phytoremediation of sites polluted with petroleum hydrocarbons. In most studies, it was discovered that grasses and legumes can be used in the remediation of crude oil polluted soils (Aprill and Sims, 1990; Qiu et al., 1997; Gunther et al., 1996; Reilley et al., 1996). April and Sims (1990) noted that prairies (grassland with tall grasses) are good for phytoremediation because of their extensive fibrous root systems. Grasses exhibit an inherent genetic diversity, which may give them a competitive advantage in becoming established under unfavorable soil conditions. On the other hand, legumes with their nitrogen fixing ability were considered to have a better phytoremediation potential over non-leguminous plants in contaminated site (Gudin and Syratt, 1975). Sequel to these potentials offered by grasses and legumes in remediation, therefore, this study was set to evaluate Eleusine indica, Panicum maximum and Lablab purpureus for their potential to remediate crude oil polluted soil in the greenhouse conditions.

\section{MATERIALS AND METHODS}

Experimental Site: The research was carried out in plastic microplots at the Centre for Ecological Studies, University of Port Harcourt. Soil was collected at a depth of $0-15 \mathrm{~cm}$ in a fallow land within the University Park. This area has no recorded incidence of accidental or deliberate oil spill. The soil was collected, bulked and homogenized thoroughly. This soil was later analyzed for its physicochemical properties which served as baseline for later analyses.

Sources of planting materials: Seeds of Lablab purpureus were obtained from the Seed Bank section of the International Institute for Tropical Agriculture (IITA), Ibadan, Nigeria. Sprouting shoots and roots of Eleusine indica and Panicum maximum were collected from a pasture area within the University Park.

The Hand Book of West African Weeds by Akobundu et. al., 2016 was used as a guide for the preliminary identification of the plants and further authenticated in the University of Port Harcourt herbarium.

Collection of crude oil: Crude oil used for this study was Bonny Light Crude. It was obtained from the Eleme Refining and Petrochemical Company, Eleme, Rivers State, Nigeria. 
The shoots and roots of the grass plants (Eleusine indica and Panicum maximum) were cut to $5 \mathrm{~cm}$ using a knife while the seeds of Lablab purpureus were raised in the nursery until they got to the three leaf stage before transplanting to micropots.

Experimental Design: Five liters plastic pots $(17.5 \mathrm{~cm}$ diameter with $25 \mathrm{~cm}$ depth) were each filled with 2 $\mathrm{kg}$ soil weighed with mettler balance. Crude oil was measured using a measuring cylinder and soil in each microplot was polluted with $0 \mathrm{ml}$ (which served as a control), $40 \mathrm{ml}, 80 \mathrm{ml}$ and $120 \mathrm{ml}$ (equivalent to 0,2, 4 and $6 \%(\mathrm{v} / \mathrm{w})$ of crude oil thoroughly mixed with soil in each microplot. Three week old seedlings of Eleusine indica, Panicum maximum and Lablab purpureus were planted randomly in each microplot in a 3 $\mathrm{X} 4$ factorial experiment laid out in a randomized complete block design (RCBD) with four replicates.

\section{Data Collection and analyses}

Data were assessed on soil physicochemical parameters, total petroleum hydrocarbon, soil $\mathrm{pH}$, soil nitrate and phosphate, total organic carbon, soil conductivity and soil cation exchange capacity. Total Petroleum Hydrocarbon content was determined in two successive phases at the pre and post remediation from soil and the test plants.

i) Petroleum hydrocarbon was extracted by measuring $10 \mathrm{ml}$ of dichloromethane using a measuring cylinder added to $2 \mathrm{~kg}$ of soil sample in a beaker. The mixture was thoroughly stirred using a magnetic stirrer and allowed to settle thereafter filtered through extraction column containing cotton wool, sodium sulphate and silica gel. The clear extract was collected into test tubes and concentrated to $2 \mathrm{ml}$ after mixing with a rotary evaporator.

ii) Gas chromatographic analysis: The concentrated extract was then used for gas chromatographic analysis in HP 5890 II GC Machine to determine the values of the various fractions of petroleum hydrocarbon present in the sample. Total petroleum hydrocarbon was obtained by summing the values of the separate fractions detected using the formula

\section{Calculation Dilution (if any) x Reading (TPH) x volume (2 ml)}

Weight of sample (2 g)

Soil $\mathrm{pH}$ was determined by measuring $50 \mathrm{~g}$ of soil sample into a beaker of $50 \mathrm{ml}$ of distilled water (i.e 1:1 v/w) stirrer for 5 minutes and allowed to stand for 30 minutes. The $\mathrm{pH}$ value was measured with a digital $\mathrm{pH}$ meter (Hanna HI 8314) by immersing the instrument's electrodes into the solution and the $\mathrm{pH}$ of the solution displayed on the equipment was recorded. Soil nitrate and phosphate were determined using a spectrophotometer. 
Total organic Carbon (TOC) was determined by measuring $1 \mathrm{~g}$ of contaminated soil samples, the soil samples were added into two conical flasks containing $10 \mathrm{ml}$ of $1 \mathrm{~N}_{\mathrm{KCr}_{2}} \mathrm{O}_{7}$ solution. The mixture was stirred thoroughly with a magnetic stirrer for 5 minutes. Four drops of Ferron (as indicator) were added to the solution and this was titrated with $0.5 \mathrm{~N}$ - ferrous sulphate solutions. Blank solution (i.e. solution without the soil sample) was prepared and also titrated $0.5 \mathrm{~N}$ - ferrous sulphate solutions and the total organic carbon compared using the equation

Total Organic Carbon $($ TOC $)=\underline{(\text { Blank }- \text { titre value }) \times 0.179}$

Weight of soil

Soil electrical conductivity was determined using the sub sample of extract previously described in the determination of $\mathrm{pH}$ above. To determine electrical conductivity, the electrodes were immersed into the extract to obtain the electrical conductivity value. Soil Cation Exchange Capacity was obtained by the determination of exchangeable acids $\left(\mathrm{H}^{+}\right.$and $\left.A l^{\mathrm{a}+}\right)$ and exchangeable cations $(\mathrm{Ca}, \mathrm{Mg}, \mathrm{Na}$ and $\mathrm{K})$ and then summing their values.

\section{Statistical Analysis:}

Factorial Analysis of Variance (FANOVA) was employed to analyze the data obtained from the experiment with SAS (statistical Package, version 9.1, 2007) and means were separated with LSD at $5 \%$ level of significance

\section{RESULTS AND DISCUSSION}

The results of the physicochemical parameters taken at the baseline stage are presented in Table 1 . The effect of some botanicals in the remediation of crude oil polluted soil at various concentrations of the soil physicochemical properties after its statistical implication (Table 2).

Table 1: Physicochemical characterization of the soil (before crude oil pollution)

\begin{tabular}{|c|c|c|c|c|c|c|c|c|c|c|c|c|c|}
\hline $\begin{array}{l}\text { Para } \\
\text { meter }\end{array}$ & $\mathrm{pH}$ & $\mathrm{O}$ & $\mathrm{N}$ & $\mathrm{P}$ & $\mathrm{Ca}$ & $\mathrm{Mg}$ & $\mathrm{K}$ & $\mathrm{Na}$ & $\mathrm{Al}$ & CEC & Clay & Silt & Sand \\
\hline & $(1: 1) \mathrm{H}_{2} \mathrm{O}$ & \multicolumn{2}{|c|}{$\%$} & \multicolumn{7}{|c|}{$\mathrm{Cmol} / \mathrm{kg}$} & \multicolumn{3}{|c|}{$\%$} \\
\hline & 4.40 & 2.51 & 0.26 & 42.71 & 20.36 & 0.66 & 0.09 & 0.69 & 0.00 & 2.12 & 14.0 & 21.4 & 64.6 \\
\hline
\end{tabular}


Table 2: Effect of some botanicals in the remediation of crude oil polluted soil

\begin{tabular}{|c|c|c|c|c|c|c|c|c|}
\hline Botanicals & $\begin{array}{l}\text { Crude oil } \\
\text { Concentration (v/w) }\end{array}$ & ТPH & $\mathrm{NO}_{3}$ & $\mathrm{PO}_{4}$ & $\mathrm{pH}$ & $\mathrm{CON}$ & TOC & CEC \\
\hline \multirow[t]{5}{*}{ Eleusine indica } & $0 \%$ (Control) & 38.30 & 9.08 & 13.67 & 5.62 & 36.67 & 2.12 & 1.94 \\
\hline & $2 \%$ & 183.30 & 5.50 & 48.43 & 4.93 & 36.67 & 1.70 & 1.72 \\
\hline & $4 \%$ & 387.90 & 10.67 & 25.37 & 4.86 & 38.00 & 1.91 & 1.86 \\
\hline & $6 \%$ & 646.20 & 17.23 & 12.30 & 4.84 & 33.33 & 2.03 & 1.89 \\
\hline & LSD & 80.10 & 1.42 & 6.03 & 1.24 & 9.35 & 0.90 & 0.49 \\
\hline \multirow{5}{*}{$\begin{array}{l}\text { Panicum } \\
\text { maximum }\end{array}$} & $0 \%$ (Control) & 37.49 & 9.00 & 13.57 & 5.52 & 33.33 & 2.07 & 1.93 \\
\hline & $2 \%$ & 192.90 & 5.70 & 49.20 & 4.88 & 36.67 & 1.70 & 1.72 \\
\hline & $4 \%$ & 378.50 & 10.63 & 24.87 & 4.86 & 38.00 & 1.76 & 1.91 \\
\hline & $6 \%$ & 619.10 & 16.73 & 11.33 & 4.90 & 33.33 & 1.73 & 1.80 \\
\hline & LSD & 82.20 & 1.46 & 5.92 & 1.35 & 7.79 & 0.91 & 0.57 \\
\hline \multirow{7}{*}{$\begin{array}{l}\text { Lablab } \\
\text { purpureus }\end{array}$} & $0 \%$ (Control) & 40.70 & 9.20 & 13.73 & 5.60 & 42.67 & 2.11 & 2.04 \\
\hline & $2 \%$ & 183.90 & 5.67 & 48.70 & 4.89 & 36.67 & 1.81 & 1.66 \\
\hline & $4 \%$ & 383.40 & 11.0 & 25.13 & 4.94 & 38.00 & 1.91 & 1.81 \\
\hline & $6 \%$ & 620.50 & 16.88 & 11.73 & 4.89 & 36.67 & 2.46 & 1.85 \\
\hline & LSD & 81.9 & 1.45 & 5.98 & 1.29 & 16.35 & 1.26 & 0.37 \\
\hline & $\mathrm{P} \geq \mathrm{F}$ (Botanical $\mathrm{X}$ & $\mathrm{ns}$ & $\mathrm{ns}$ & ns & $\mathrm{ns}$ & ns & $\mathrm{ns}$ & $\mathrm{ns}$ \\
\hline & Treatment & & & & & & & \\
\hline
\end{tabular}

Where: $\mathrm{TPH}=$ total petroleum hydrocarbon; $\mathrm{NO}_{3}=$ nitrate $; \mathrm{PO}_{4}=$ phosphate $; \mathrm{CON}=$ conductivity; $\mathrm{TOC}=$ total Organic Carbon; $\mathrm{CEC}=$ cation exchange capacity; ns = not significant

The result of this study showed that total petroleum hydrocarbon was significantly reduced $(\mathrm{p} \leq 0.05)$ in all treatments by the test plants. P. maximum had the highest remediation effect on total petroleum hydrocarbon (TPH). P. maximum reduced TPH by $94.1 \%$ in soil polluted by $4 \% \mathrm{v} / \mathrm{w}$ of crude oil. This was closely followed by soil treated with $6 \% \mathrm{v} / \mathrm{w}$ of crude oil with $94 \%$ reduction of TPH. This is similar with the woks of Hutchinson et al. (2001) and McIntosh et al. (2017) who stated reduction of TPH by grasses in polluted soil thereby making the soil better and free of hydrocarbon.

Lablab purpureus planted in $2 \% \mathrm{v} / \mathrm{w}$ crude oil polluted soil significantly reduced TPH by $82.5 \%$ compared with the control. In addition, $L$. purpureus planted in the various concentrations of crude oil in the soil significantly ( $\mathrm{p} \leq 0.05$ ) reduced TPH by $88.4 \%$ and $93.7 \%$ in $3 \%$ and $4 \% \mathrm{v} / \mathrm{w}$, respectively compared with the control (Table 2). Eleusine indica had the lowest level of TPH degradation when compared with $P$. maximum and $L$. purpureus. E. indica significantly $(\mathrm{p} \leq 0.05)$ reduced TPH by $89.3 \%$ and $91.4 \%$ in the $4 \% \mathrm{v} / \mathrm{w}$ and $6 \% \mathrm{v} / \mathrm{w}$ concentrations in crude oil in the soil when compared with the control. The higher rate of TPH remediation in $P$. maximum could be as a result of their fibrous root system; with a large root length and surface area per volume of surface soil. The fibrous root provides for colonization by micro-organisms than a tap root as reported by April and Sims (1990). Zhang et al. (2009) observed that phytoremediation in grasses attain remediation range of 2.33 - 3.19 times higher than the un-vegetated control. There was no significant $(\mathrm{p} \leq 0.05)$ remediation of nitrates and phosphates by test plants in this study (Table 1). However, there was significant $(\mathrm{p} \leq 0.05)$ difference from baseline, pre-remediation and post remediation concentrations of soil nitrate. The difference in phosphate values across the treatments was not significant. The inability of the plants to 
remediate these two essential nutrients can be explained as a result of the stress undergone by the plants. The nutrients were quickly used up to enable plants survive the polluted environment. At the pre-remediation stage, $\mathrm{pH}$ level of the soil was 4.40 . There was a significant decrease in soil $\mathrm{pH}$ which ranged from 5.25-6.08 by all the test plant as this is an indication of weak soil acidity post remediation. This result could be attributed to the fact that soil bacteria thrive better in neutral soils than acidic soils, the increase of the soil $\mathrm{pH}$ towards neutral condition means more favorable conditions for soil bacteria and these bacteria play good role in the degradation of crude oil. The optimum pH range for most plants is between 5.5 and 7. (Perry, 2012; Anyanwu et $a l ., 2014)$. Conductivity was reduced at the pre-remediation stage. There was no significant $(\mathrm{p} \leq 0.05)$ difference in conductivity values of Eleusine indica, Panicum maximum, Lablab purpureus in the three stages of this study (pre remediation stage, vegetative stage of plant and post remediation stage). A drop in the cation exchange capacity (CEC) of the soil at pre-remediation stage was observed in all treatments. At post remediation, there was no restoration of CEC to the baseline level. The differences between the baseline and post remediation values of CEC were not significant at $\mathrm{p} \leq 0.05$. There was significant ( $\mathrm{p} \leq 0.05$ ) difference in the baseline, pre-remediation and post remediation values of total organic carbon. In all the test plants, it was only Panicum maximum was able to remediate the soil back to the baseline total organic carbon (TOC) level in the crude oil polluted soil.

\section{CONCLUSION}

With the increasing cases of spillage and vandalisation of crude oil pipelines in Nigeria especially in the Niger-Delta region, a cheap and eco-friendly approach in the management and improving the status of crude oil polluted soils. The remediation potentials of the test plants and control followed an increasing significant performance order: control < Eleusine indica $<$ Lablab purpureus < Panicum maximum. Therefore, Panicum maximum and Lablab purpureus are promising plants with phytoremediation potentials that could be deployed to degrade total petroleum hydrocarbon and fixing nitrogen in the soil in order to improve soil quality and health.

\section{REFERENCES}

Akobundu, I. O., Ekeleme, F., Agyakwa, C. W.and Ogaziem C.A (2016). A handbook of West African weeds. International Institute of Tropical Agriculture, Ibadan, Nigeria 3rd Edition.

Anderson, T. A., Guthrie, E. A. and Walton, B. T. (1993). Bioremediation in the rhizosphere: Plant roots and associated microbes clean contaminated soil. Environ. Sci. Technol. 27: 2630-2636.

Anyanwu, D.I, Awi-Waadu, G.D.B., Tanee, F.G.B and Ochekwu, E.B (2014): Fundamental principles of Ecology. M \& J Grand Orbit Communications LTD. 12 / 14 Okoeoma (njemenze street), elechi layout, mile 1, Diobu, Port Harcourt, Nigeria, ISBN $978-978-33527-0-9$

Aprill, W. and Sims, R. C. (1990). Evaluation of the use of prairie grasses for stimulating polycyclic aromatic hydrocarbon treatment in soil. Chemosphere 20 (1-2): 253-265.

Gudin, C. and Syratt, W. J. (1975). Biological aspects of land rehabilitation following hydrocarbon contamination. Environmental Pollution 8: 107-112.

Gunther, T., Dornberger, U. and Fritsche, W. (1996). Effects of ryegrass on biodegradation of hydrocarbons in soil. Chemosphere. 33 (2): 203-215.

Hutchinson, S.l1.., banks, M.K. and Schwab, A.P. (2001): Phytoremediation of Aged petroleum sludge: Effect of Inorganic fertilizer. Journal of Environmental quality. $\mathrm{Vol}$ 30(2): 395 - 403

McIntosh, P.,chulthess,C.P., Kuzovkina, Y.A. and Guillard,K. (2017): Bioremediation and phytoremediation of Total petroleum hydrocarbon (TPH) under various conditions. International Journal of Phytoremediation. 19(3): 753 - 764

www.scirj.org

(C) 2020, Scientific Research Journal

http://dx.doi.org/10.31364/SCIRJ/v8.i4.2020.P0420764

This publication is licensed under Creative Commons Attribution CC BY. 
Ochekwu, E.B. and Madagwa, B. (2013) Phytoremediation potentials of water hyacinth Eichhornia crassipes (mart.) Solms in crude oil polluted water. J. Appl. Sci. Environ. Manage. 17(14): 503-507.

Qiu, X., Leland, T. W., Shah, S. I., Sorensen, D. L. and Kendall, E. W. (1997). Grass remediation for clay soil contaminated with polycyclic aromatic hydrocarbons. In: Phytoremediation of soil and water contaminants. Kruger,V T. Anderson, A. and Coats, J. R. American Chemical Society: Washington, D.C. ACS Symposium Series 664.186-199.

Perry, L. (2012): pH for the Gardens. University of Vermont Extension. Department of Plant and Soil Science.

Raskin, .I. (1996). Plant Genetic Engineering. Proc. Nat. Acad. Sci. 93; 3164-3166.

Reilley, K. A., Banks, M. K. and Schwab, A. P. (1996). Organic chemicals in the environment: Dissipation of polycyclic aromatic hydrocarbons in the rhizosphere. Journal of Environmental Quality 25: 212-219.

SAS Institute Inc, (2007) Version 9.1 SAS for windows (Statiscal analysis) SOFTWARE INSTITUTE, INC (Cary, NC USA).

Zhang, Z. Z., Su, S. M., Luo, Y. J. and Lu, M. (2009). Improvement of natural microbial remediation of petroleum-polluted soil using graminaceous plants. Water Sci. Technol. 29(5): 1025-1035. 